\title{
Penggunaan RFID (Radio Frequency Identification) CT-1809 Untuk Prototype Pendeteksi Sarana Berbasis Arduino Uno
}

\section{The Application of RFID (Radio Frequency Identification) CT-1809 for The Facility Detection Prototype based on Arduino Uno}

\author{
Teguh Arifianto ${ }^{1, *}$, Dwiki Bagas Setyawan ${ }^{2}$, Sunaryo $^{3}$ \\ 1,2,3 Program Studi Teknologi Elektro Perkeretaapian, Politeknik Perkeretaapian Indonesia Madiun \\ Jl. Tirta Raya, Pojok, Nambangan Lor, Kec. Manguharjo, Madiun 63161, Jawa Timur, Indonesia \\ 1,*Penulis korespondensi: teguh@ppi.ac.id, \\ ${ }^{2}$ dwiki.tep1811@taruna.ppi.ac.id, ${ }^{3}$ sunaryo @ppi.ac.id
}

Received on 05-08-2021, accepted on 30-10-2021, published on 01-11-2021

\begin{abstract}
Abstrak
Bencana alam seperti banjir dan longsor merupakan suatu halangan bagi suatu perjalanan transportasi khususnya kereta api yang dapat merugikan dari segi materi maupun korban jiwa. Banjir dapat menyebabkan rel putus dan error pada track circuit karena pada LCP terdeteksi terdapat sarana diatas jalur. Penelitian ini bertujuan untuk membuat alat deteksi sarana menggunakan teknologi RFID (Radio Frequency Identification) yang dapat mengantisipasi banjir saat mendeteksi sarana. Diperlukannya sebuah teknologi untuk mendeteksi sarana dengan lebih efisien, penulis menggunakan mikrokontroler Arduino Uno untuk mengontrol dan transfer data RFID dari transmitter ke receiver, proses transfer data tersebut menggunakan komunikasi nrikabel nRF24L01 dan menghasilkan output berupa identitas kereta pada LCD 16x2. Pendeteksian sarana menggunakan RFID mampu berjalan dengan baik pada jarak $250 \mathrm{~cm}$, untuk pengirman data menggunakan nRF24l01 terdapat range delay memiliki range delay dari 1,64 detik sampai 3,25 detik.
\end{abstract}

Kata Kunci: Arduino uno, Banjir, Deteksi sarana, Komunikasi nirkabel, nRF24L01, RFID

Abstract

Natural disasters such as floods and landslides are an obstacle to a transportation journey, especially trains, which can be detrimental in terms of material and loss of life. For instance, floods can cause rails to break and errors in the track circuit because the LCP (Local Control Panel) is detected as having facilities above the track. This study aims to create a means of detecting facilities using RFID (Radio Frequency Identification) technology which can anticipate flooding when detecting facilities. The need for technology to detect facilities more efficiently, the author uses an Arduino Uno microcontroller to control and transfer RFID data from the transmitter to the receiver, the data transfer process uses nRF24L01 wireless communication module and produces output in the form of a Train identity on a 16×2 LCD. Detection of facilities using RFID is able to run well at a distance of $250 \mathrm{~cm}$ by sending data by the nRF24l01 module. The delay range is 1.64 seconds to 3.25 seconds.

Keywords: Arduino uno, Facility detection, Flood, nRF24L01, RFID, Wireless communication 


\section{Pendahuluan}

Pendeteksi sarana perkeretaapian merupakan peralatan yang digunakan untuk mendeteksi keberadaan sarana pada jalur kereta api baik di emplasmen maupun di petak jalan [1]. Pendeteksi terdiri dari dua jenis yaitu axle counter dan track circuit. Dalam bidang transportasi khususnya kereta api, perjlanan kereta api sangat berpengaruh terhadap berbagai sapek, salah satunya adalah bencana alam banjir. Track circuit sendiri mempunyai kelemahan rentan terhadap petir dan air yang menyebabkan sistem elektrik mengalami gangguan [2]. Oleh karena itu, sarana tidak dapat terdeteksi yang menyebabkan Pengatur Perjalanan Kereta Api atau PPKA tidak dapat mengetahui jalur mana yang terdapat sarana tanpa melihat langsung ke petak jalan. Untuk pendeteksian kereta pada jalur kereta api dan meningkatkan keamanan pada jalur kereta api diperlukan suatu alat detector kereta yang mampu bekerja sebagai identitas bagi kereta itu sendiri saat keadaan banjir.

Dengan alat deteksi sarana ini maka kereta dapat dipantau dengan mudah dan efisien karena sistem monitoring yang dapat mengidentifikasi kereta. Akhir-akhir ini pengembangan teknologi berkembang begitu cepat pada seluruh sektor. Maka penulis berasumsi bahwa perlu dilakukan peningkatan output deteksi kereta untuk meningkatkan keamanan pada jalur kereta api, contoh peristiwa non kecelakaan terjadi pada KM $58+1 / 3$ lintas Stasiun Pasuruan dan Stasiun Bangil dimana banjir melanda sepanjang 200 meter dan menyebabkan perjalanan kereta KA Mutiara Timur dan KA Probowangi berhenti, setelah banjir agak surut maka dilakukan perbaikan konstruksi badan rel, dan setelah dilakukan perbaikan kereta dapat melaju dengan kecepatan maksimal 5 km/jam dan menyebabkan keterlambatan selama 15-20 menit [3].

Alat detektor ini adalah alat untuk mendeteksi kereta yang dilengkapi penomoran terhadap kereta itu sendiri dengan menggunakan RFID (Radio Frequency Identification) yang mempunyai cara kerja memantulkan frekuensi radio. Detektor ini menggunakan RFID tag yang terpasang pada kereta sebagai transmitter dan RFID reader sebagai receiver yang dipasang pada lintas.

\section{Tinjauan Pustaka}

Alat deteksi sarana dengan identitas penomoran menggunakan RFID CT-I809 sebagai tag atau identitas pada kereta dan RFID reader CT-I809 sebagai receiver atau penerima sinyal dari tag RFID dengan kata lain RFID memiliki TX dan RX. Tag RFID sendiri mempunyai dua jenis yaitu aktif dan pasif, dua tag tersebut mempunyai perbedaan yaitu tag aktif mempunyai catu daya sendiri sehingga jarak pendeteksian lebih maksimal tetapi mempunyai umur yang relatif pendek, sedangkan tag pasif tidak mempunyai catu daya sendiri yang mengakibatkan jarak pendeteksian lebih minim.hanya sampai beberapa meter dikarenakan menggunakan gelombang radio dari reader RFID tetapi mempunyai umur yang relatif panjang, cara kerja alat ini yaitu apabila kereta yang telah dipasangi tag RFID yang sebelumnya telah diberi identitas penomoran lalu melewati reader dari RFID maka data output berupa visual identitas kereta tersebut terlihat pada LCD. Data yang masuk sebelumnya diproses oleh dua arduino dengan dengan komunikasi NRF24L01 antar Arduino.

RFID adalah proses identifikasi objek dengan menggunakan frekuensi radio. RFID menggunakan frekuensi radio untuk membaca informasi dari sebuah devais kecil yang disebut tag atau transponder (Transmitter + Responder). Pada sistem RFID umumnya, tag atau transponder ditempelkan pada suatu objek. Setiap tag membawa informasi yang unik yang bisa diubah sewaktu-waktu sesuai kebutuhan. Ketika tag ini melalui medan yang masuk radius deteksi, tag akan mentransmisikan informasi yang ada pada tag kepada pembaca RFID, sehingga proses identifikasi objek dapat dilakukan dan data dari tag dapat diperoleh [4].

Arduino Uno merupakan mikrokontroler AVR berbasis Atmega328 yang memiliki pin input/output sebanyak 14 pin, dimana 6 pin dapat digunakan sebagai output PWM, 6 pin untuk input analog, resonator keramik 16MHz, sambungan USB, jack power, header ICSP, dan tombol reset. Arduino Uno berfungsi sebagai otak dari sistem elektronika yang minimalis dan efisien yang dapat diprogram dengan software Arduino IDE dengan USB sebagai media komunikasi antara arduino dan laptop [5].

Modul nRF24L01 merupakan modul komunikasi wireless jarak jauh yang menggunakan frekuensi gelombang radio 2.4-2.5 GHz dan memiliki kecepatan pengiriman data sampai dengan $2 \mathrm{Mbps}$ dan 
menggunakan Serial Peripheral Interface (SPI) untuk berkomunikasi. Modul ini dapat tersinkronisasi dengan Arduino uno [6].

\section{Metode Penelitian}

Alat monitoring sarana menggunakan RFID ini akan di analisa dengan metode eksperimental, yaitu metode penelitian yang digunakan untuk mencari pengaruh perlakuan tertentu terhadap yang lain dalam kondisi yang terkendalikan [7]. Ketika alat berjalan sesuai dengan fungsi yang diharapkan, maka alat dikatakan berhasil. Namun, apabila alat yang telah diaplikasikan tidak bekerja sesuai dengan fungsinya, maka alat tersebut dikatakan tidak berhasil. Maka dari itu, pengujian terhadap alat perlu dilaksanakan. Hasil pengujian inilah yang akan digunakan untuk menganalisa penentuan keberhasilan perancangan alat. Percobaan uji coba dilakukan dengan pengambilan hasil data dari alat dengan empat parameter uji yaitu pengujian deteksi jarak tag dengan metode cut off, pengujian jarak komunikasi antara transmitter dan receiver dengan metode cut off menggunakan stopwatch, pengujian kecepatan deteksi tag menggunakan sepeda motor dan metode menghitung mean delay, pengujian deteksi tag horizontal dan vertikal dengan meter ukur. Metode cut off dapat dilihat pada Persamaan 1 [8] dan perhitungan mean delay dapat dilihat pada persamaan 2 [9]

$$
\text { Cut off point }=(\text { maximum score }+ \text { minimum score }) / 2
$$

Rata-rata delay $=$ Total delay $/$ Total paket yang diterima

\section{A. Alur Penelitian}

Flowchart merupakan penggambaran secara grafik dari langkah-langkah dan urutan prosedur suatu program [10]. Rancangan ini mengidentifikasi komponen-komponen suatu sistem informasi yang akan dirancang secara detail seperti pada gambar 1. 


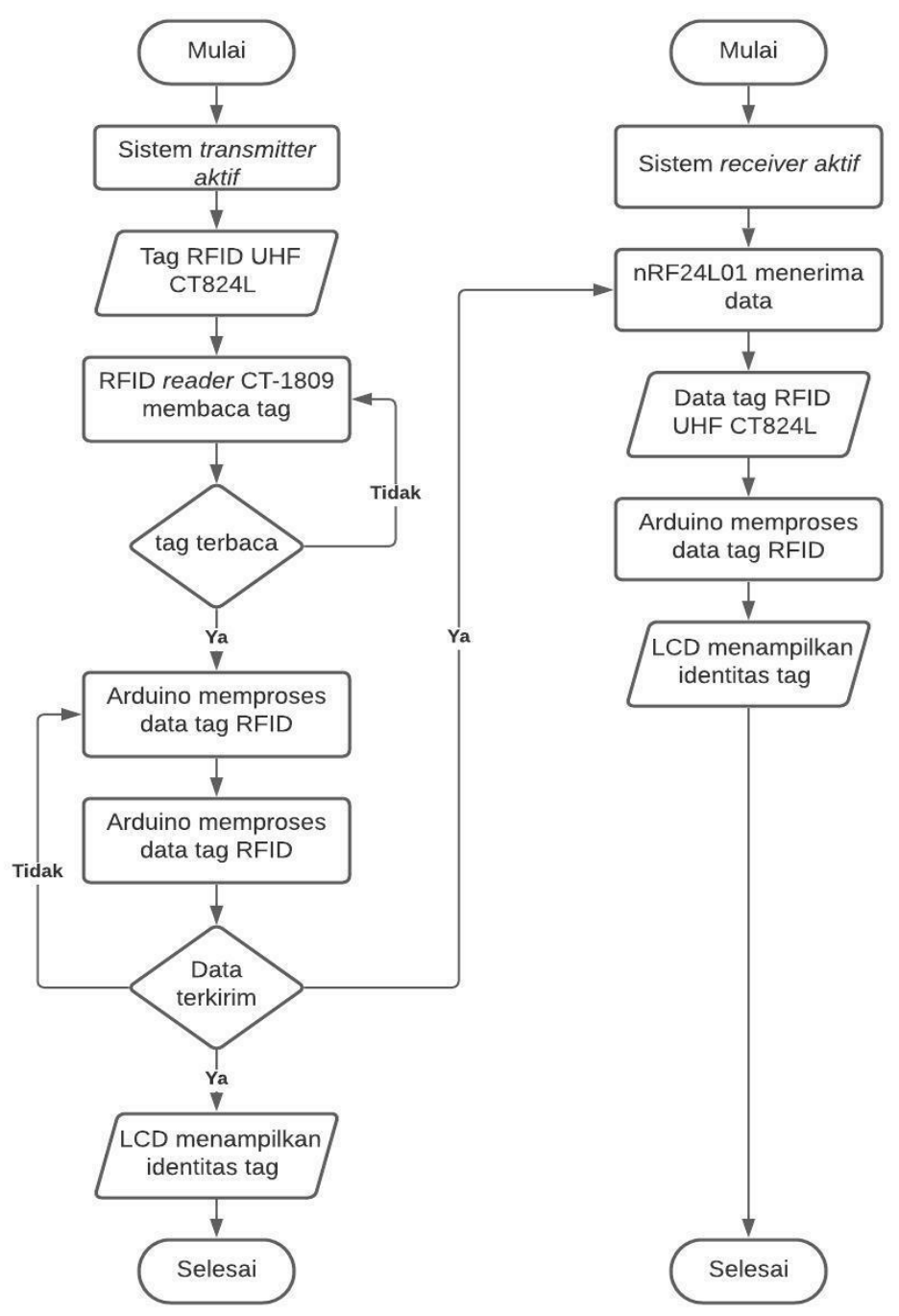

Gambar 1. Flowchart sistem kerja alat 


\section{B. Blok Diagram Sistem Kerja}

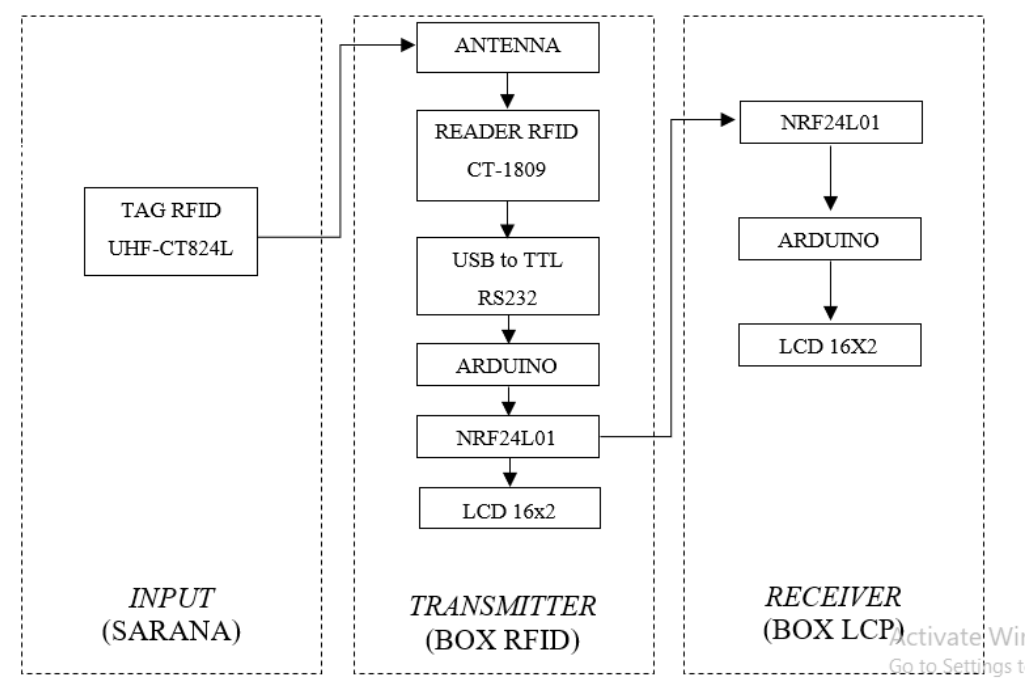

Gambar 2. Blok diagram sistem kerja

Penjelasan dari diagram blok diatas yaitu RFID yang terdiri dari dua bagian yaitu reader dan transmitter saling berkaitan, saat tag mendapatkan input berupa frekuensi radio yang di pancarkan oleh reader maka tag akan mengirimkan identitas dari tag tersebut dan diterima kembali oleh reader. Selanjutnya Arduino Uno akan menerima hasil input dari reader dengan komunikasi RS232. Sedangkan untuk nRF24L01 digunakan untuk komunikasi antara dua arduino untuk saling transfer data inputan. Setelah diterima oleh nRF24L01 arduino yang berperan sebagai receiver memproses data dan output berupa identitas kereta sebagai hasil dari pembacaan tag pada LCD 16x2.

\section{Skema Rangkaian Sistem}

Sistem mengandung arti kumpulan-kumpulan dari komponen-komponen yang dimiliki unsur keterkaitan antara satu dengan lainnya [11].

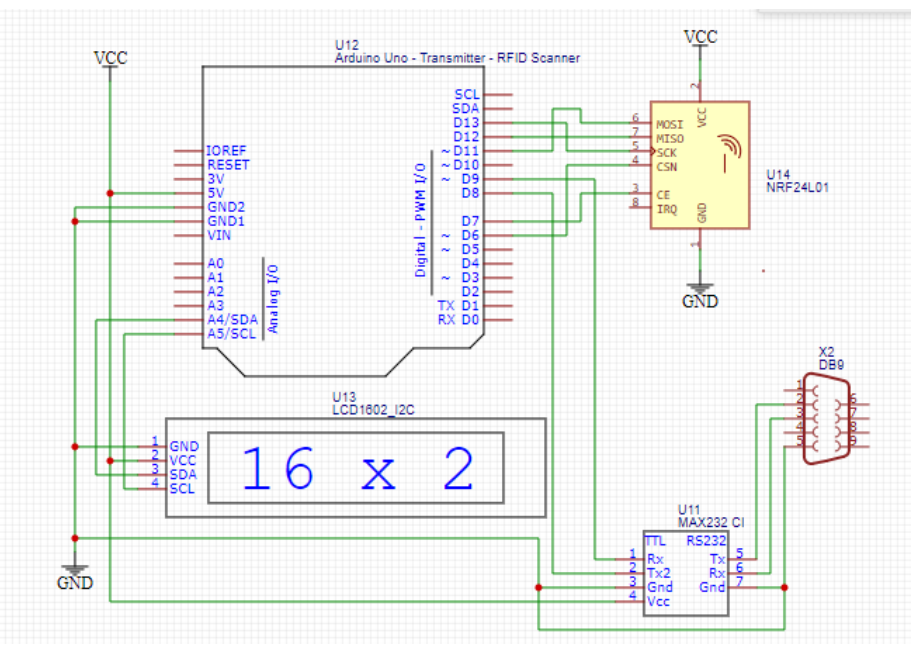

Gambar 3. Skema rangkaian sistem transmitter

Gambar 3 merupakan skema rangkaian sistem transmitter digambar menggunakan software online EasyEDA. Terdapat beberapa komponen hardware seperti Arduino Uno, I2C LCD 16x2, RS232, 
nRF24L01, kabel jumper, Female Header 1x40, Male Header 1x40 adaptor 9V. Komponen hardware tersebut berfungsi untuk memproses data input dari tag RFID dan olahan data tersebut dikirm ke receiver.

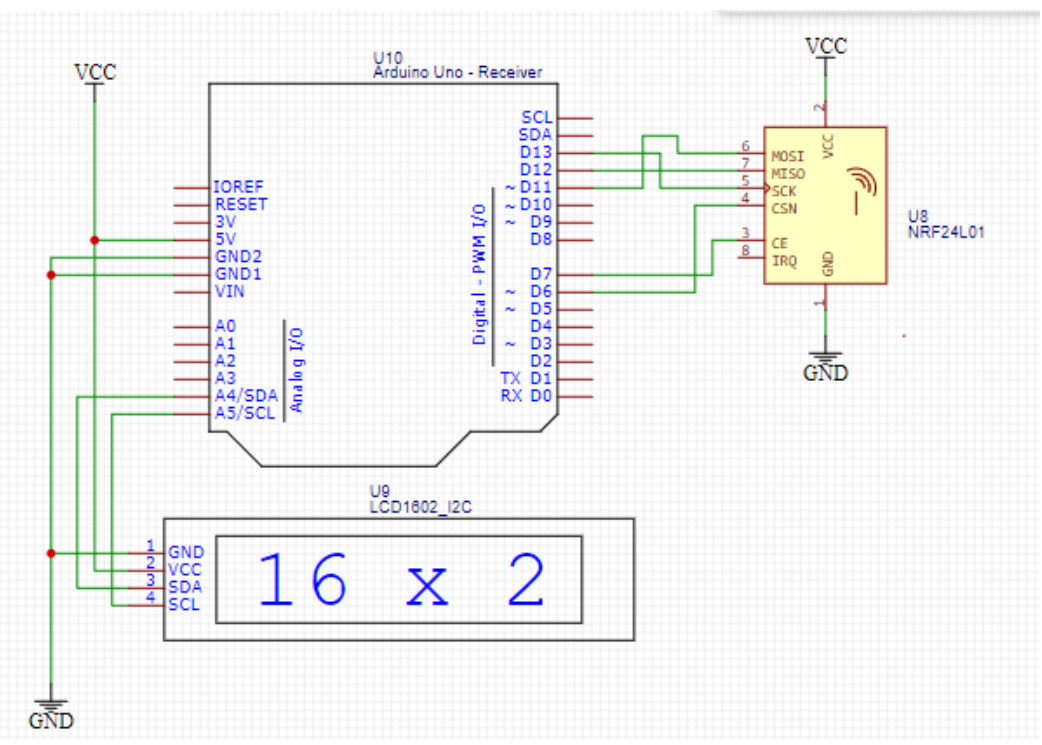

Gambar 4. Skema rangkaian sistem receiver

Gambar 4 merupakan skema rangkaian sistem transmitter digambar menggunakan software online EasyEDA. Terdapat beberapa komponen hardware seperti Arduino Uno, I2C LCD 16x2, nRF24L01, kabel jumper dan adaptor 9V. Komponen hardware tersebut berfungsi untuk memproses data input dari transmitter RFID yang berupa identitas tag dan olahan data tersebut dikirm ke LCD yang berupa output dari olahan data.

\section{Desain LCP dan box RFID}

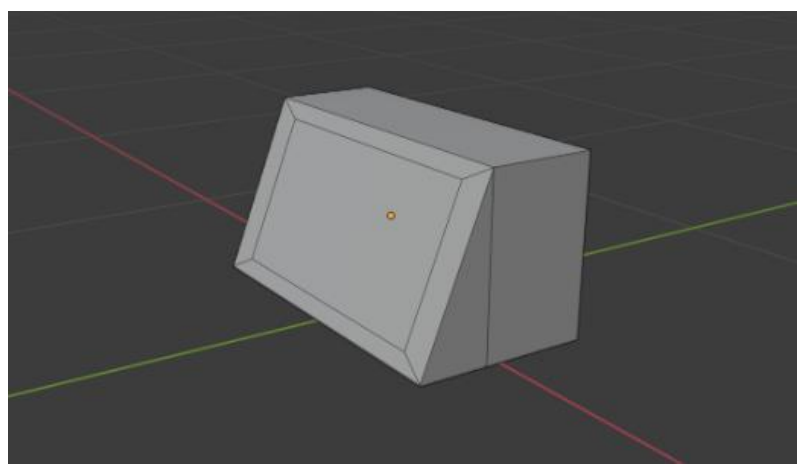

Gambar 5. Perancangan desain LCP 


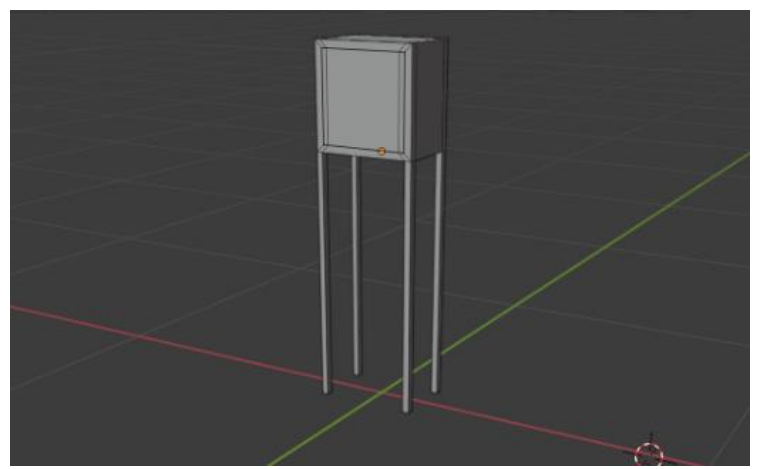

Gambar 6. Perancangan desain box RFID

Perancangan desain LCP dan box RFID dilakukan menggunakan software Blender. Dalam perancangan ini dibutuhkan bahan yang dibuat secara kokoh dan kuat yaitu untuk LCP menggunakan playwood dan stainlees steel, sedangkan untuk box RFID menggunakan plat besi agar praktis dalam perakitannya.

\section{Hasil dan Pembahasan}

\section{A. Pengujian Jarak Deteksi Tag}

Pengujian ini terdiri dari pembacaan tag dengan kelipatan jarak $50 \mathrm{~cm}$ dengan 20 kali percobaan setiap jaraknya menggunakan Persamaan 1.

Tabel 1. Hasil pengujian jarak deteksi tag

\begin{tabular}{|c|c|c|}
\hline Jarak $(\mathbf{c m})$ & Cut-off & Keterangan \\
\hline 50 & 10 & Terdeteksi \\
\hline 100 & 10 & Terdeteksi \\
\hline 150 & 10 & Terdeteksi \\
\hline 200 & 10 & Terdeteksi \\
\hline 250 & 13,5 & Kurang Terdeteksi \\
\hline 300 & 15,5 & Kurang Terdeteksi \\
\hline 350 & 20 & Tidak Terdeteksi \\
\hline 400 & 20 & Tidak Terdeteksi \\
\hline
\end{tabular}

Dari tabel 1 dapat diketahui hasil pengujian jarak deteksi tag setelah dilakukan 20 kali percobaan dengan jarak antara reader dan tag kelipatan $50 \mathrm{~cm}$, dengan hasil tag satu dan tag dua dapat terdeteksi dengan baik oleh RFID tanpa adanya error pada jarak $200 \mathrm{~cm}$, untuk jarak 250 - $300 \mathrm{~cm}$ tag kurang terdeteksi dan untuk jarak $350-400 \mathrm{~cm}$ tag tidak dapat terdeteksi. Kesimpulan pengujian dapat dilihat pada gambar 7 .

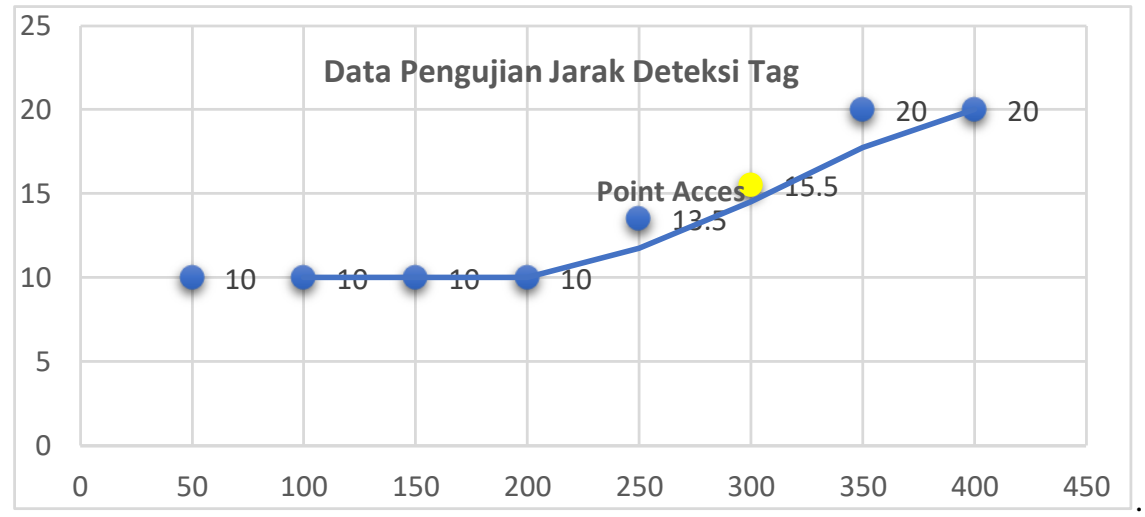

Gambar 7. Grafik pengujian jarak deteksi tag 


\section{B. Pengujian Komunikasi Transmitter dan Receiver}

Pengujian ini terdiri dari percobaan komunikasi antara receiver dan transmitter dengan 5 kali percobaan setiap 25 meter sampai dengan jarak 150 meter dengan menggunakan Persamaan 2 untuk mencari mean dari delay.

Tabel 2. Hasil pengujian komunikasi transmitter dan receiver

\begin{tabular}{|c|c|c|}
\hline Jarak (m) & Data yang diterima & Delay (detik) \\
\hline 25 & 5 & 1,66 \\
\hline 50 & 5 & 1,71 \\
\hline 75 & 5 & 2,07 \\
\hline 100 & 5 & 2,40 \\
\hline 125 & 5 & 2,89 \\
\hline 150 & 5 & 3,12 \\
\hline Jumlah & 30 & 13,85 \\
\hline
\end{tabular}

Dari tabel 2 dapat diketahui hasil pengujian komunikasi untuk mencari mean delay antara transmitter dan receiver dengan Persamaan 2, dengan jumlah data 30 dan jumlah paket yang diterima 13,85 detik maka mean delay adalah 0,461 detik. Dalam pengujian tidak terdapat error saat melakukan pengiriman data menggunakan komunikasi nRF24L01, tetapi terdapat range delay dari 1,64 detik sampai 3,25 detik. Grafik kesimpulan dari pengujian ini dapat dilihat pada gambar 8.

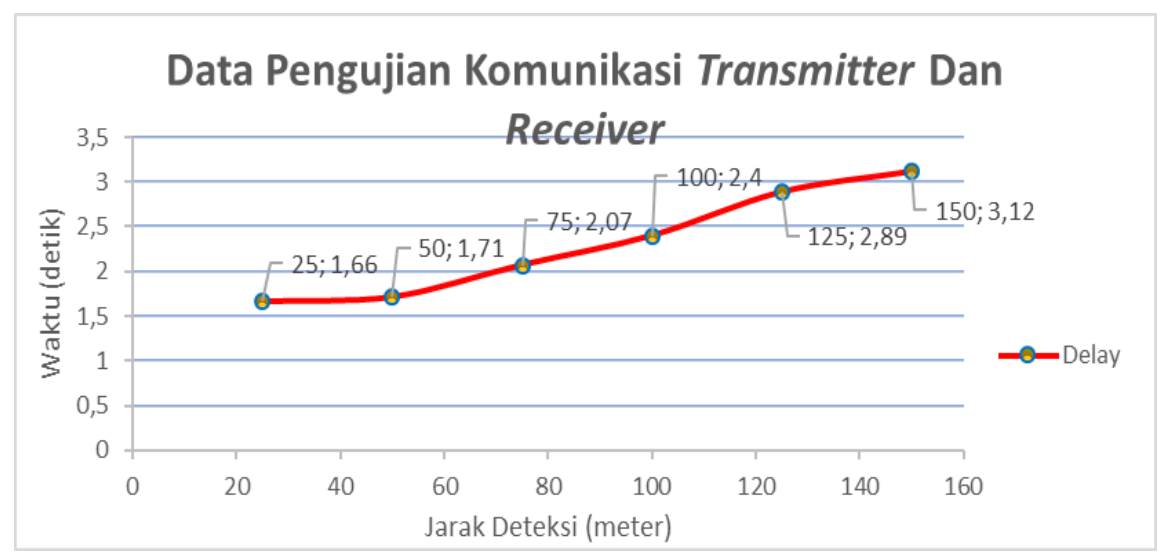

Gambar 8. Grafik pengujian komunikasi nRF24L01

\section{Pengujian Kecepatan Deteksi Tag RFID}

Pengujian ini terdiri dari pembacaan tag dengan kecepatan 10-30 km/jam dilakukan 10 kali percobaan pada setiap kecepatanya, menggunakan Persamaan 1 untuk mengetahui tag terdeteksi atau tidak pada kecepatan tertentu.

Tabel 3. Hasil pengujian kecepatan deteksi tag RFID

\begin{tabular}{|c|c|c|}
\hline Kecepatan(km/jam) & Cut-off & Keterangan \\
\hline 10 & 5 & Terdeteksi \\
\hline 15 & 5 & Terdeteksi \\
\hline 20 & 5 & Terdeteksi \\
\hline 25 & 6 & Kurang Terdeteksi \\
\hline 30 & 6,5 & Kurang Terdeteksi \\
\hline
\end{tabular}


Dari tabel 4.3 dapat diketahui hasil pengujian deteksi tag dengan kecepatan uji $10-30 \mathrm{~km} / \mathrm{jam}$ setelah dilakukan percobaan 10 kali percobaan, hasil yang didapat tag dapat terdeteksi dengan baik pada kecepatan 10-20 km/jam, terdapat error pada kecepatan 25-30 km/jam dikarenakan terdapat noise berupa manusia yang lewat. Grafik kesimpulan dari pengujian ini dapat dilihat pada gambar 9.

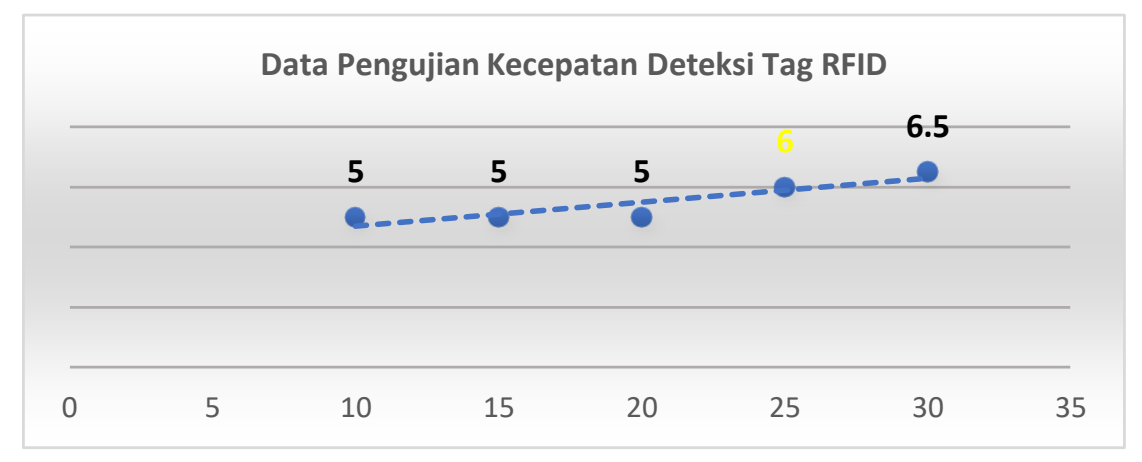

Gambar 9. Grafik pengujian kecepatan deteksi tag RFID

\section{Pengujian Deteksi Tag Horizontal dan Vertikal Tag RFID}

Pengujian ini terdiri dari pendeteksian tag dengan dengan jarak horizontal dan vertikal. Percobaan dilakukan sebanyak 20 kali pada setiap jarak vertikal $50 \mathrm{~cm}$, menggunakan Persamaan 1 untuk mengetahui jarak loss dalam pendeteksian tag.

Tabel 4. Hasil pengujian deteksi tag horizontal dan vertikal

\begin{tabular}{|c|c|c|}
\hline Jarak (cm) & Cut-off & Keterangan \\
\hline 50 & 17,5 & Terdeteksi \\
\hline 100 & 15 & Terdeteksi \\
\hline 150 & 12,5 & Terdeteksi \\
\hline 200 & 10 & Terdeteksi \\
\hline
\end{tabular}

Dari tabel 4.4 diatas dapat diketahui bahwa setelah dilakukan percobaan 20 kali terhadap jarak vertikal 50-200 cm dan jarak horizontal 10-200 cm. Hasil yang didapat dengan Persamaan 1 tag dapat terdeteksi dengan jangkauan $45^{\circ}$ dengan kesimpulan grafik seperti pada gambar 10 sebagai berikut.

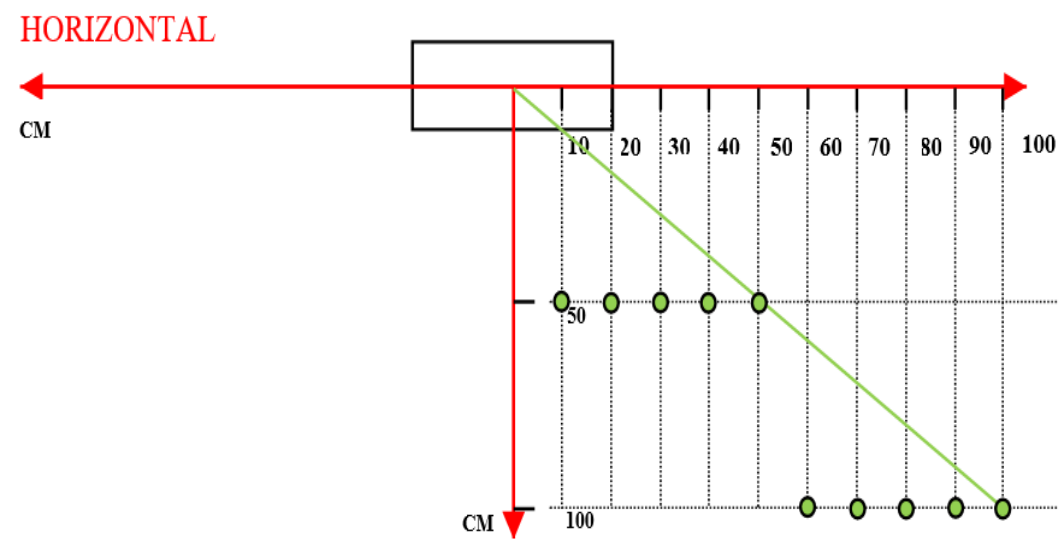

VERTIKAL

Gambar 10. Hasil tag dengan jangkauan $45^{\circ}$ 


\section{KESIMPULAN}

Dari hasil pembuatan alat yang berjudul Rancang Bangun Prototype Pendeteksi Sarana Menggunakan RFID (Radio Frequency Identification) Type CT-1809 Berbasis Arduino Uno dapat diambil kesimpulan sebagai berikut:

Perancangan prototipe deteksi sarana menggunakan RFID tipe CT-1809 menggunakan Arduino Uno sebagai pemroses input dan output, pengiriman data dari tag yang telah diberi identitas menggunakan komunikasi antar nRF24L01. Variabel penelitian meliputi pengaturan jarak deteksi tag, delay komunikasi antara transmitter dan receiver, kecepatan deteksi tag dan deteksi tag secara horizontal dan vertikal telah berhasil dilakukan.

Hasil pengujian beberapa perangkat dapat disimpulkan bahwa jarak deteksi tag setelah dilakukan 20 kali percobaan dengan jarak antara reader dan tag kelipatan $50 \mathrm{~cm}$, dengan hasil tag satu dan tag dua dapat terdeteksi dengan baik oleh RFID tanpa adanya error pada jarak $200 \mathrm{~cm}$, untuk jarak $250-300 \mathrm{~cm}$ tag kurang terdeteksi dan untuk jarak $350-400 \mathrm{~cm}$ tag tidak dapat terdeteksi. Untuk pengujian komunikasi antar transmitter dan receiver dengan pengujian komunikasi untuk mencari mean delay dengan jumlah data 30 dan jumlah paket yang diterima 13,85 detik maka mean delay adalah 0,461 detik, terdapat range delay dari 1,64 detik sampai 3,25. Dapat disimpulkan bahwa semakin jauh jarak antara dua nRF24L01 maka delay pengiriman data akan semakin lama. Untuk pengujian kecepatan deteksi tag dengan hasil pengujian kecepatan uji 10-30 km/jam setelah dilakukan percobaan 10 kali percobaan, hasil yang didapat tag dapat terdeteksi dengan baik pada kecepatan 10-20 km/jam, terdapat error pada kecepatan 25-30 km/jam dikarenakan terdapat noise berupa manusia yang Untuk pengujian pendeteksian tag secara horizontal dan vertikal diketahui bahwa setelah dilakukan percobaan 30 kali terhadap jarak vertikal 50-200 $\mathrm{cm}$ dan jarak horizontal 10-200 $\mathrm{cm}$. Kesimpulan dari pengujian ini adalah pola pembacaan tag dengan jarak vertikal dan horizontal mencapai jangkauan $45^{\circ}$

\section{UCAPAN TERIMA KASIH}

Tim penulis menyampaikan terima kasih kepada semua Dosen Teknologi Elektro Perkeretaapian dan Kepala Subbagian Administrasi Akademik (Sunaryo, M.Sc) Politeknik Perkeretaapian Indonesia Madiun yang telah memberikan dukungan moril dan materiil selama pelaksanaan penelitian.

\section{Kontribusi Penulis}

Teguh Arifianto menjalankan simulasi dan analisis hasil penelitian. Dwiki Bagas Setyawan merancang dan menjalankan simulasi. Sunaryo melakukan analisis hasil penelitian dan melakukan ujicoba simulasi sesuai dengan perancangan yang telah disusun.

\section{Daftar Pustaka}

[1] Pemerintah Indonesia, 2018., Peraturan Menteri No. 44 Tahun 2018 Tentang Persyaratan Teknis Peralatan Persinyalan Perkeretaapian

[2] Fatkhan, B. N., Ramdhani, M., Sugiana, M. T. E. A., \& Si, S. (2021). Sistem Deteksi Keberadaan Kereta Api Menggunakan Induksi Magnetik Train Presence Detection System Using Magnetic Induction. 8(2), 1011-1020.

[3] Dinas Komunikasi dan Informatika Provinsi Jawa Timur., http://kominfo.jatimprov.go.id/read/umum/jalur-rel-pasuruanbangil-sudah-bisa-dilewati-kereta-api, Diakses pada 1 Agustus 2021.

[4] Wahono S., 2020., Sistem Keamanan Parkir Berbasis RFID dan Plat Nomor Kendaraan Menggunakan Metode Leptonica., Surabaya: Universitas Dinamika.

[5] Syahputra N., 2021., Rancang Bangun Sistem Sensor Smart Dustbin Dengan Konsep Smart Assistant Berbasis IOT Menggunakan Arduino Uno., Medan: Universitas Sumatera Utara.

[6] Shobrina U. J., 2018., Analisis Kinerja Pengiriman Data Modul Transceiver nRF24L01, Xbee dan Wifi ESP8266 Pada Wireless Sensor Network., Malang: Universitas Brawijaya.

[7] Sugiyono, 2018., Metode Penelitian Kuantitatif, Kualitatif, dan R\&D. Bandung Alfabeta.

[8] Sarjono, H. 2015., Pengukuran Kinerja Dengan Pendekatan Metode Cut-off Point. 50-66.

[9] Wulandari R., 2016., Analisis QoS ( Quality Of Service) Pada Jaringan Internet ( Studi Kasus : UPT Loka Uji Teknik Penambangan Jampang Kulon - Lipi ). 2, 162-172.

[10] Indrajani, 2011., Perancangan Basis Data dalam All in 1. Jakarta: PT. Elex Media Komputindo.

[11] Indrajit, 2001., Analisis dan Perancangan Sistem Berorientasi Object. Bandung: Informatika. 